\title{
Ankara İli Kırsal Alanda Süt Tüketim Düzeylerinin Belirlenmesi
}

\author{
Yasemin DEMIR ${ }^{*}$ \\ Erdoğan GÜNEȘ² \\ 'Toprak Gübre ve Su Kaynakları Merkez Araștırma Enstitüsü Müdürlüğü, Ankara \\ ${ }^{2}$ Ankara Üniversitesi Ziraat Fakültesi Tarım Ekonomisi Bölümü, Ankara
}

\begin{abstract}
* Sorumlu yazar e-posta (Corresponding author e-mail): yasemindemir@tarim.gov.tr Geliș tarihi (Received) : 15.01.2017

Kabul tarihi (Accepted): 03.03.2017

Öz

Bu çalıșmada kırsal alanda tarımsal üretim faaliyetinde bulunan hane halklarının süt tüketim düzeyleri ve tercihleri incelenmiștir. Bu doğrultuda Ankara iline bağı Polatlı, Beypazarı, Ayaș ilçelerinde 122 birey ile 2016 yılının Nisan-Mayıs aylarında yüz yüze görüșmeler yoluyla anketler yapılmıștır. Anket sonuçlarını yorumlamak için basit aritmetik ortalama, oranlama, yüzde hesapları ve $\chi 2$ analizi kullanılmıștır. Görüșülen ailelerin hanehalkı genișliği ortalama 3.6 kiși ve ortalama süt tüketimi kiși bașına yıllık 28.4 It olarak belirlenmiștir. İșletmelerin \%59'unda süt üretimi yapılırken, yapılan $\chi 2$ analizi sonucunda ailelerin süt tüketim düzeylerinin ișletmelerin süt üretiminde bulunma durumuna ve ișletme sahiplerinin yaș gruplarına bağlı olarak değiștiği belirlenmiștir.
\end{abstract}

Anahtar Kelimeler: Süt, tüketim, Ankara, kırsal Alan

\section{The determination of milk Consumption Level in Ankara Province}

\begin{abstract}
In this study, milk consumption levels and preferences of producers operating in agricultural sector in rural areas were analyzed. In this direction, polls of Ankara, Polatli, Beypazarı, Ayaș provinces were interviewed by face-to-face interviews with 122 producers in April-May 2016. In order to interpret the survey results, simple arithmetic mean, ratio, percentage calculations, graph and $\chi 2$ analysis were used. In the interviews, the average household size of the producers is composed of 3.6 persons and the average milk consumption per capita is 28.4 It per capita. While milk production was conducted in $59 \%$ of the household establishments, it was determined that milk consumption levels of the families as a result of the $\chi 2$ analysis changed according to the presence of milk production and the age groups of the business owners.
\end{abstract}

Key words:Milk, consumption, Ankara, rural area 


\section{Giriș}

Süt ve süt ürünleri özellikleri bakımından insan sağlığı için her gün tüketilmesi gereken gıda maddeleri arasında yer almaktadır. Sütün en verimli ve yaygın olduğu șekli içme sütü olarak kullanılmasıdır. Bunun en önemli nedeni, sütün çeșitli biçimlerde mamul maddelerle ișlenmesi ve dayanıklı hale sokulması sırasında bileșimindeki bazı besin elementlerinde kayıpların ortaya çıkmasıdır (Çetinkaya, 2010). Yapılan araștırmalarda 1 bardak sütle 6 yașındaki bir çocuğun günlük intiyac olan B12 vitamininin \%98'inin, fosforun $\% 55$ 'inin, kalsiyumun \%52'sinin, B12 vitamininin \%44'ünün karșılandığı, özellikle çocukların güçlü kemik yapısına sahip olması için süt tüketiminin çok önemli olduğu belirtilmektedir (Anonim, 2016a). Bununla birlikte hayatın belirli dönemlerinde süt tüketiminin önemi büyüktür. Ergenlik, yetișkinlik ve yașlllık dönemlerinde, menopoz döneminde, hamilelik ve emzirme sürecinde önerilen süt tüketim miktarı süt ürünlerinin tüketimi haricinde günlük 2 su bardağıdır (Anonim, 2016b). Kısaca cinsiyet ve yaș grubu ayrımı yapmaksızın her insanın günlük beslenmesine süt ürünlerinin yanı sıra sütü özellikle dahil etmesi gerekmektedir.

Süt tüketimi ülkeler için bir gelișmișlik göstergesi olarak görülmektedir. Birçok Avrupa ülkesinde ve Avustralya'da kiși bașına yıllık süt tüketimi 100 kg'ı așmakta, ABD ve Kanada'da 100 kg'a yaklașmaktadır (Anonim 2016c). Ancak Türkiye'de kayıt altına alınan süt üretim miktarları ve dıș ticaret verileri dikkate alındığında kiși bașına içme sütü tüketiminin 37 kg'a yakın olduğu tahmin edilmektedir (Onurlubaș ve Çakırlar, 2016). Bu nedenle gerek sağlık uzmanları, gerekse konuyla ilgili yapılan araștırmalar süt tüketiminin önemine ișaret etmekte ve tüketimin artırılması için uyarılarda bulunmaktadır.

Süt tüketim düzeyi genel olarak düșük olmasıyla birlikte sosyo-ekonomik faktörler de bu düzeyi etkilemektedir. Yapılan çalıșmalarda da süt tüketim miktarları ve harcamalarda süte ayrılan paylar farklııı göstermektedir. Grigg (1999), Akdeniz ülkelerinde yaptığı çalıșmasında gıda tüketim modellerini incelemiș ve bölgesel farklılıklar gösterdiğini belirtmiștir. Bunun yanı sıra Akbay ve Tiryaki (2007)'nin çalıșmalarında, eğitim düzeyi ve gelir ile süt tüketimi arasında pozitif bir ilișki olduğunu süt tüketim alıșkanlıkları ile gelir, eğitim, yaș, cinsiyet ve annenin statüsü arasında yakın ilișki olduğunu belirtmișlerdir. Hanta (1994) Adana ili kentsel alanda 200 ailenin hayvansal gıda tüketim yapısını incelemiș ve toplam hayvansal gıda tüketim harcamaları içinde süt ve süt ürünleri harcamalarının oranını \%33.2 olarak hesaplamıștır. Șimșek ve ark. (2005) İstanbul ilinde ailelerin içme sütü ile ilgili alıșkanlıklarını belirlemek için yaptıkları araștırmalarında, yıllık kiși bașına süt tüketim miktarını 34 It olarak hesaplamıșlardır. Armağan ve Akbay (2008) ise Aydın ili kentsel alanında bazı hayvansal ürünler tüketiminin ekonometrik analizini yapmıșlar ve yılda kiși bașına $48.2 \mathrm{~kg}$ içme sütü tüketildiğini hesaplamıșlardır. Çetinkaya (2010) Kafkas Üniversitesi'ndeki öğrencilerin süt ve süt ürünleri tüketimini incelemiș, öğrencilerin $\% 33$ 'ünün süt tükettiği, \%67'sinin ise hiç süt tüketmediğini ve büyük çoğunluğunun düzenli süt tüketimi alıșkanlığının olmadığını tespit etmiștir.

Bu araștırmada kentsel alanda yapılan çalıșmaların yanında kırsal alanda konuyla ilgili yapılan çalıșmaların azlığı nedeniyle tarımsal faaliyette bulunan ailelerde süt tüketim düzeyleri ve çeșitli parametreler arasında ilișkiler incelenmiștir.

\section{MATERYAL VE YÖNTEM}

\section{Materyal}

Araștırmanın ana materyalini, Ankara iline bağlı ilçelerde tarım sektöründe faaliyet gösteren ve kırsal alanda yașayan üreticilerle yüz yüze anket yöntemiyle elde edilen veriler olușturmuștur.

İkincil veriler ise konu ile ilgili daha önce yapılmıș çalıșmalar ile Türkiye İstatistik Kurumu istatistiki kayıtlarından ve çeșitli sivil toplum örgütlerinin yayınlandığı verilerden meydana gelmiștir.

\section{Yöntem}

\section{Örnekleme Sırasında Uygulanan Yöntem}

Araștırmada Ankara ilinde kırsalda tarımsal üretimde bulunan ișletmelerin tamamı ile görüșmek, ekonomik ve teknik açıdan mümkün olamayacağı için örnekleme yapılması uygun görülmüștür. Popülasyonu olușturan 2014 yılı Çiftçi Kayıt Sistemi verilerine göre ișletmelerin kayıtlı ișletme arazisi genișlikleri dikkate alınarak tabakalı örnekleme yöntemine göre \% 90 güven sınırları ile anket uygulanacak örnek ișletme sayıları bulunmuștur (Yamane, 2001). 
$\mathrm{n}=\frac{\left[N \sum N_{h} S_{h}^{2}\right]}{N^{2} D^{2}+\sum N_{h} S_{h}^{2}}$

$\mathrm{n}$ = örnek ișletme sayısı

$N_{\mathrm{h}}=$ h'ıncı tabakadaki ișletme sayısı

Sh = h'ıncı tabakanın standart sapması

$N=$ Toplam ișletme sayısı

$D^{2}=(d / t)^{2}$ değeri olup.

$d$ = Popülasyon ortalamasından izin verilen hata miktarını (Ortalama arazi genișliğinin \%10'u).

$\mathrm{t}=$ Araștırmada öngörülen \%90 güven sınırına karșilık gelen t tablo değerini ifade etmektedir.

Araștırmada anketlerininyapılacağıilçelersosyoekonomik farklılıklar göz önünde bulundurularak gayeli örnekleme yöntemi ile seçilmiștir. Seçilen ilçeler Ankara ili için üretimin yoğun yapıldığı, ürün çeșitliliğinin fazla olduğu ilçelerdir. Bu doğrultuda üretici anket uygulamalarının Polatlı, Beypazarı ve Ayaș ilçelerinde yapılmasına karar verilmiștir. Uygulanacak toplam anket sayısı 122 olarak hesaplanmıș ve anketlerin 82'si Polatlı, 20'si Ayaș, 20'si Beypazarı ilçelerinde 2016 yılı Nisan ve Mayıs ayları arasında yapıımıștır.

Çizelge 1. Anket Yapılan Gruplar ve Anket Sayıları

Table 1. Survey Groups and Survey Numbers

\begin{tabular}{ccc} 
Da & Varyasyon Katsayısı & Anket Sayısı \\
\hline$<41$ & 39.41 & 34 \\
$41-150$ & 36.00 & 30 \\
$151-400$ & 28.02 & 40 \\
$400+$ & 38.43 & 18
\end{tabular}

Toplam: 122
Anket yapılan ilçelere ait köyler, bölgedeki dağıım ve tarımsal potansiyel dikkate alınarak amaçlı olarak belirlenmiș, tesadüfi olarak seçilen ișletmelerde uygulanmıștır. Polatlı ilçesinde Basri, Yeni Köseler, Ömerler, Beyliköprü, Cekirdeksiz, Karacaahmet, Gedikli, Karahamzalı, Yassıhüyük, Tatlıkuyu köylerinde, Beypazarı ilçesinde Dikmen, Dibecik, Fasıl, Oymaağaç, Yoğunpelit, Tacettin, Acısu, Tahirler, Harmancık köylerinde ve Ayaș ilçesinde Oltan, Ilıca, Akkaya, Sinanlı, İlhan, Evci köylerinde anketler tamamlanmıștır.

Araștırmada üreticilerin demografik özellikleri, ekonomik yapıları, eğitim durumları, süt tüketim tercihleri gibi özellikler basit aritmetik ortalama, oransal hesaplama, indeks hesaplama yöntemleriyle gösterilmiștir. Çalıșmanın konusu olan süt tüketim tercihleri hakkında belirlenen faktörler ve sosyo-ekonomik göstergeler arasındaki ilișkiler, Ki-kare ( $\chi 2$ ) (Düzgüneș ve ark. 1993, Sokal ve Rohlf 1995) analiziyle açıklanmıștır.

Ki-kare analizi, gözlenen frekanslar ile beklenen frekanslar arasındaki farkın istatistik olarak anlamlı olup olmadığı temeline dayanır. Ki-kare dağıımı, genellikle iki bağımsız niteliksel kriteri test etmek için kullanııır. Sıfır hipotezi, iki kriterin bağımsız olduğunu; araștırma hipotezi ise, iki kriterin arasında ilișki olduğunu ifade eder (Güngör ve Bulut, 2008).

\section{BULGULAR VE TARTISMA}

Üreticilerin yașları üç gruba ayrılarak ișletme büyüklüklerine göre Çizelge 2'de verilmiștir. Bu gruplamaya göre 30 ve daha küçük yaș grubunda olan üreticiler anket yapılan ișletmelerin yalnızca \%4.1'ni olușturmaktadır. Çoğunluk ise 50 yaș ve üzerindeki ișletme sahiplerinden olușmaktadır.

Çizelge 2. İșletme Büyüklük Gruplarına Göre Üreticilerin Yaș Grupları

Table 2. Age Groups of Farmers by Farm Size Groups

\begin{tabular}{|c|c|c|c|c|c|c|}
\hline \multirow[t]{2}{*}{ Yaș } & \multicolumn{5}{|c|}{ Gruplar } & \multirow[b]{2}{*}{ Toplam } \\
\hline & & $<41$ & $41-150$ & $151-400$ & $>400$ & \\
\hline \multirow[t]{2}{*}{$\leq 30$} & Sayı & 4 & - & 1 & - & 5 \\
\hline & Oran & 11.8 & & 2.5 & & 4.1 \\
\hline \multirow[t]{2}{*}{$31-49$} & Sayı & 19 & 11 & 18 & 3 & 51 \\
\hline & Oran & 55.9 & 36,7 & 45.0 & 16.7 & 41.8 \\
\hline \multirow[t]{2}{*}{$\geq 50$} & Sayı & 11 & 19 & 21 & 15 & 66 \\
\hline & Oran & 32.3 & 63.3 & 52.5 & 83.3 & 54.1 \\
\hline \multirow[t]{2}{*}{ Toplam } & Sayı & 34 & 30 & 40 & 18 & 122 \\
\hline & Oran & 100 & 100 & 100 & 100 & 100 \\
\hline
\end{tabular}


İncelenen ișletmelerde üreticilerin eğitim durumları arazi büyüklük gruplarına göre Çizelge 3'de verilmiștir. Küçük yașta aile ișletmesinde çalıșmaya bașlayan üreticilerin eğitimi büyük çoğunlukla ilkokul düzeyinde kalmaktadır. Görüșülen üreticilerin \%85,2'si ilkokul mezunudur.

İșletmelerin süt üretim faaliyet yapısı incelendiğinde, bunların \%59'unun süt sığırına sahip olduğu ve ișletmelerin süt üretimi yaptığı belirlenmiștir (Çizelge 4). Görüșülen ișletmelerin hiçbirinde koyun veya keçi sütü üretilmediği belirlenmiștir.

İșletmelerin ortalama gelirleri, aylık ortalama gıda harcamaları ve süt harcamaları Çizelge 5 'de verilmiștir. Buna göre araștırma alanında ișletme büyüklüğü arttıkça doğru orantılı olarak gelir ve gıda harcamalarında da artıș olduğu görülmüștür. Ortalama süt harcamalarının düșüklüğü, üreticilerin kendi ürettiği sütü tüketmelerinden kaynaklanmaktadır.

Çalıșmada ișletmelerde hane halkı genișliği ortalama 3.7 kiși olarak hesaplanmıștır. Ortalama aylık süt tüketimi aile bașına 11.7 It ve kiși bașına yıllık süt tüketim ise 28.4 It olarak hesaplanmıștır (Çizelge 6). Bu miktar hem Türkiye ortalamasından hem de önerilen miktarlardan düșüktür. Çelik ve ark. (2005), Șanlıurfa kentsel alanda yaptıkları çalıșmalarında aileler genelinde ortalama aylık süt tüketimi miktarını 16.2 litre olarak belirlemișlerdir.

Süt tüketim miktarları ișletmelerin süt üretimi yapma durumlarına göre incelendiğinde, üretimin olduğu ișletmelerde süt tüketiminin de arttığı görülmüștür (Çizelge 7). Süt üretimi yapan ișletmelerin \%50'si aylık aile bașına 1 1-20 It arasında süt tüketirken, üretim yapmayan ișletmelerde aile bașına aylık tüketim \%58 oranında 5 It'nin altında

Çizelge 3. İșletme Büyüklük Gruplarına Göre İșletme Yöneticilerinin Eğitim Durumu

Table 3. Educational Situations of Farmers by Farm Size Groups

\begin{tabular}{|c|c|c|c|c|c|c|}
\hline \multirow[t]{2}{*}{ Eğitim Durumu } & \multicolumn{5}{|c|}{ Gruplar } & \\
\hline & & $<41$ & $41-150$ & $151-400$ & $>400$ & \\
\hline \multirow[t]{2}{*}{ Okur-Yazar Değil } & Sayı & - & - & 1 & - & 1 \\
\hline & Oran & & & 2,50 & & 0.8 \\
\hline \multirow[t]{2}{*}{ İlkokul } & Sayı & 25 & 26 & 36 & 17 & 104 \\
\hline & Oran & 73.5 & 86.7 & 90.0 & 94.4 & 85.2 \\
\hline \multirow[t]{2}{*}{ Lise } & Sayı & 8 & 4 & 3 & 1 & 16 \\
\hline & Oran & 8.8 & 13.3 & 10.0 & 5.6 & 9.8 \\
\hline \multirow[t]{2}{*}{ Yük.Okul-Üniversite } & Sayı & 1 & - & - & - & 1 \\
\hline & Oran & 2,9 & - & - & - & 0,8 \\
\hline \multirow[t]{2}{*}{ Toplam } & Sayı & 34 & 30 & 40 & 18 & 122 \\
\hline & Oran & 100 & 100 & 100 & 100 & 100 \\
\hline
\end{tabular}

Çizelge 4. İșletme Büyüklük Gruplarına Göre Süt Üretimi Yapma Durumu

Table 4. Milk Production Status by Farm Size Groups

\begin{tabular}{|c|c|c|c|c|c|c|}
\hline \multirow[t]{2}{*}{ Süt Üretimi Yapma Durumu } & \multicolumn{5}{|c|}{ Gruplar } & \multirow[b]{2}{*}{ Genel (122) } \\
\hline & & $<41$ & $41-150$ & $151-400$ & $>400$ & \\
\hline \multirow[t]{2}{*}{ Evet } & Sayı & 19 & 18 & 23 & 12 & 72 \\
\hline & $\%$ & 55.9 & 60.0 & 57.5 & 66.7 & 59.0 \\
\hline \multirow[t]{2}{*}{ Hayır } & Sayı & 15 & 12 & 17 & 6 & 50 \\
\hline & $\%$ & 42.9 & 40.0 & 42.5 & 33.3 & 41.0 \\
\hline \multirow[t]{2}{*}{ Toplam } & Sayı & 34 & 30 & 40 & 18 & 122 \\
\hline & $\%$ & 100.0 & 100.0 & 100.0 & 100.0 & 100.0 \\
\hline$\chi^{2}=0.624$ & & $P=0.891$ & & & & \\
\hline
\end{tabular}


Çizelge 5. İșletme Büyüklük Gruplarına Göre Gelir Durumları, Gıda ve Süt Harcamaları

Table 5. Income Situations, Food and Milk Expendituresby Farm Size Groups

\begin{tabular}{llllll}
\multirow{2}{*}{ Değișken } & \multicolumn{4}{c}{ Gruplar } & \\
\cline { 2 - 5 } & $<41$ & $41-150$ & $151-400$ & $>400$ & Genel (122) \\
\hline Ortalama Gelir (TL/Ay) & 902.9 & 1178.3 & 1254.5 & 1486.1 & 1172.0 \\
\hline Gıda Harcamaları (TL/ay) & 251.1 & 298.1 & 331.8 & 346.9 & 303.3 \\
\hline Süt Harcamaları (TL/ay) & 13.5 & 10.3 & 10.5 & 5.0 & 10.5 \\
\hline
\end{tabular}

Çizelge 6. İșletme Büyüklük Gruplarına Göre Hanehalkı Genișliği ve Süt Tüketim Miktarları

Table 6. Household Width and Milk Consumption Quantitiesby Farm Size Groups

\begin{tabular}{llllll}
\hline \multirow{2}{*}{ Değișken } & \multicolumn{5}{c}{ Gruplar } \\
\cline { 2 - 5 } & $<41$ & $41-150$ & $151-400$ & $>400$ & Genel (122) \\
\hline Hanehalkı Genișliği(Kiși) & 3.4 & 3.5 & 3.9 & 4.1 & 3.7 \\
\hline Süt Tüketimi(It/ay) & 9.9 & 9.3 & 7.4 & 6.3 & 8.4 \\
\hline Kiși Bașına Süt Tüketimi (It/Yıl) & 36.1 & 32.1 & 23.7 & 18.2 & 28.4 \\
\hline
\end{tabular}

Çizelge 7. İșletmelerin Süt Üretimi Yapma Durumuna Göre Süt Tüketim Düzeyleri

Table 7. Milk Consumption Levels by Milk Production Status

\begin{tabular}{|c|c|c|c|c|c|c|}
\hline \multirow[t]{2}{*}{ Süt Üretimi Yapma Durumu } & \multicolumn{5}{|c|}{ Gruplar } & \multirow[b]{2}{*}{ Genel (122) } \\
\hline & & $1-5$ & $6-10$ & $11-20$ & $>20$ & \\
\hline \multirow[t]{2}{*}{ Evet } & Sayı & 12 & 19 & 36 & 5 & 72 \\
\hline & $\%$ & 16,7 & 26,4 & 50.0 & 6.9 & 100.0 \\
\hline \multirow[t]{2}{*}{ Hayır } & Sayı & 29 & 11 & 9 & 1 & 50 \\
\hline & $\%$ & 58.0 & 22.0 & 18.0 & 2.0 & 100.0 \\
\hline \multirow[t]{2}{*}{ Toplam } & Sayı & 41 & 30 & 45 & 6 & 122 \\
\hline & $\%$ & 33.6 & 24.6 & 36.9 & 4.9 & 100.0 \\
\hline$\chi^{2}=24.891$ & & $P=0.000$ & & & & \\
\hline
\end{tabular}

Çizelge 8. Yaș Gruplarına Göre Süt Tüketim Düzeyleri

Table 8. Milk Consumption Levels by Age Groups

\begin{tabular}{lllllll}
\hline \multirow{2}{*}{ Yaș Grupları } & \multicolumn{7}{c}{ Süt Tüketimi (It/ay) } & Genel (122) \\
\cline { 2 - 6 } & \multicolumn{7}{c}{$1-5$} & $6-10$ & $11-20$ & $>20$ & 5 \\
\hline \multirow{2}{*}{30} & Sayı & 2 & - & 2 & 1 & 4.1 \\
\hline \multirow{2}{*}{$31-49$} & Sayı & 8 & 13 & 26 & 4 & 51 \\
& $\%$ & 19.5 & 43.3 & 57.8 & 66.7 & 41.8 \\
\hline \multirow{2}{*}{$\geq 50$} & Sayı & 31 & 17 & 17 & 1 & 66 \\
& $\%$ & 75.6 & 56.7 & 37.8 & 16.7 & 54.1 \\
\hline \multirow{2}{*}{ Toplam } & Sayı & 41 & 30 & 45 & 6 & 122 \\
& $\%$ & 100.0 & 100.0 & 100.0 & 100.0 & 100.0 \\
\hline$\chi^{2}=19.454$ & DF $=6$ & $P=0.003$ & & & & \\
\hline
\end{tabular}


Çizelge 9. İșletme Büyüklük Gruplarına Göre Süt Temin Yerleri

Table 9. Milk Supply Locationsby Farm Size Groups

\begin{tabular}{|c|c|c|c|c|c|c|}
\hline \multirow[t]{2}{*}{ Süt Temin Yöntemi } & \multicolumn{5}{|c|}{ Gruplar } & \multirow[b]{2}{*}{ Genel (122) } \\
\hline & & $<41$ & $41-150$ & $151-400$ & $>400$ & \\
\hline \multirow[t]{2}{*}{ İșletmede Üretilen } & Sayı & 19 & 18 & 23 & 12 & 72 \\
\hline & $\%$ & 55.9 & 60.0 & 57.5 & 66.7 & 59.0 \\
\hline \multirow[t]{2}{*}{ Komșulardan Açık Süt } & Sayı & 11 & 10 & 14 & 6 & 41 \\
\hline & $\%$ & 32.4 & 33.3 & 35.0 & 33.3 & 33.6 \\
\hline \multirow[t]{2}{*}{ Ambalajlı Süt } & Sayı & 4 & 2 & 3 & - & 9 \\
\hline & $\%$ & 11.7 & 6.7 & 7.5 & & 7.4 \\
\hline \multirow[t]{2}{*}{ Toplam } & Sayı & 34 & 30 & 40 & 18 & 122 \\
\hline & $\%$ & 100 & 100 & 100 & 100 & 100 \\
\hline$\chi^{2}=2.532 \quad D F=6$ & & $=0.86$ & & & & \\
\hline
\end{tabular}

Çizelge 10. Süt Temininde Etkili Faktörler

Table 10. Effective Factors for Milk Supply

\begin{tabular}{|c|c|c|c|c|c|c|}
\hline \multirow[t]{2}{*}{ Değișken } & \multicolumn{5}{|c|}{ Gruplar } & \multirow[b]{2}{*}{ Genel (122) } \\
\hline & & $<41$ & $41-150$ & $151-400$ & $>400$ & \\
\hline \multirow[t]{2}{*}{ Güvenilir Oıması } & Sayı & 4 & 2 & 4 & 1 & 11 \\
\hline & $\%$ & 26.7 & 16.6 & 23.5 & 16.7 & 22.0 \\
\hline \multirow[t]{2}{*}{ Hijyenik Olması } & Sayı & 8 & 5 & 9 & 4 & 26 \\
\hline & $\%$ & 53.3 & 41.7 & 53.0 & 66.6 & 52.0 \\
\hline \multirow[t]{2}{*}{ Akrabalık-Komșuluk } & Sayı & 3 & 5 & 4 & 1 & 13 \\
\hline & $\%$ & 20.0 & 41.7 & 23.5 & 16.7 & 26.0 \\
\hline \multirow[t]{2}{*}{ Toplam } & Sayı & 15 & 12 & 17 & 6 & 50 \\
\hline & $\%$ & 100 & 100 & 100 & 100 & 100 \\
\hline$\chi^{2}=2.483$ & & $P=0.870$ & & & & \\
\hline
\end{tabular}

kalmaktadır. Tüm ișletmelerin \%36.9'u aylık 11 ile 20 It arasında süt tüketmektedir. Yapılan $\chi 2$ analizi sonucunda ailelerin süt tüketim düzeylerinin ișletmelerin süt üretimi yapma durumuna bağlı olarak değiștiği belirlenmiștir $\chi 2=24.891 \mathrm{P}=$ 0.000).

Çizelge 8'de görüldüğü gibi ailelerin süt tüketim düzeyleri yaș gruplarına göre incelendiğinde, süt tüketiminin ișletme sahibinin yașı arttıkça azaldığı, ailelerin süt tüketim düzeylerinin ișletme sahibinin yașına bağlı olarak değiștiği belirlenmiștir. $(\chi 2=$ $19.454 \mathrm{P}=0.003)$. Benzer șekilde Onurlubaș ve Çakırlar (2016) gençlerin yașılıara göre daha fazla süt tükettiğini belirtmișlerdir.

Ailelerin süt temin yerleri incelendiğinde, ișletmelerinde süt hayvanı bulunmayan üreticiler büyük oranda komșularından açık süt almakta, ișletmelerin \% \% $u$ ise ambalajlı süt tercih etmektedir (Çizelge 9). Kentsel alanda da hijyen açıdan sakıncalı etkileri bulunan açık sütün aileler arasında tercih edildiğini gösteren araștırmalar da bulunmaktadır. Erdal ve Tokgöz (2011) ailelerin \%67.8'ünün açık sütü tercih ettiğini, \%32.2'sinin ise ambalajlı süte yöneldiğini yaptıkları araștırmada ortaya koymușlardır.

Süt üretimi yapmayan ișletme sahiplerinin süt temininde dikkat ettiği hususlar Çizelge 10'da verilmiștir. Üreticiler süt alırken \%52 oranında hijyenik olmasına dikkat etmektedir. Ayrıca ișletmelerin \%26'sı ise komșuluk-akrabalık ilișkisi nedeniyle süt temin yerini tercih etmektedir. 


\section{SONUÇ VE ÖNERILER}

Türkiye'de nüfusun yaklașı 1/3'ü tarımsal faaliyetlerle geçimini sağlamakta ve bu kesimin büyük çoğunluğu kırsalda özellikle de köylerde yașamaktadır. Araștırmanın inceleme konusu olan süt, insan beslenmesi açısından gereklidir ve Türkiye'nin önemli bir süt üreticisi olması bu yönden avantaj yaratmaktadır. Türkiye İstatistik Kurumu verilerine göre dünyada inek sütü üretiminde 8. sırada yer almaktadır. Üretimin bu derece önemli olușuna karșın tüketim düzeyi beklenenin altındadır. Yapılan araștırmalar ülkemizde süt tüketiminin düșük düzeylerde olduğunu göstermektedir. Bu araștırmada Ankara ili kırsal alanında tarımda faaliyette bulunan tarım ișletmelerinde süt tüketim eğilimi ve etkili faktörler ve faktörler arası ilișkiler ortaya konulmuștur.

Özetle, görüșülen üreticilerin büyük çoğunluğu 50 yaș üzerinde ve ilkokul mezunudur. İșletmelerin aylık ortalama gelirleri 1172 TL ve aylık gıda harcamaları 303 TL'dir. İșletme sahiplerinin hanehalkı genișliği ortalama 3.7 kișidir. Süt tüketimi ortalama olarak aile bașına aylık 11.7 It ve kiși bașına yıllık ise 28.4 It olarak hesaplanmıștır. Bu miktarlar Türkiye ortalamasının altındadır ve kırsal alandaki ailelerin süt tüketimine yeterince önem vermediğini göstermektedir.

Araștırma alanında hanehalklarının süt tüketim düzeylerinin ișletmelerin süt üretme durumuna bağlı olarak değiștiği belirlenmiștir. Üretimin olmadığı hanelerde gıda tüketimi içinde süte fazla yer verilmediği ve bu konuda satın alma gücü yetersizliği yanında alıșkanlığın etkisi ile süt tüketimi için çaba gösterilmediği anlașılmaktadır. Ayrıca süt tüketiminin ișletme sahibinin yașı arttıkça azaldığı ve süt tüketim düzeyinin ișletme sahibinin yașına bağı olarak değiștiği belirlenmiștir. Yapılan araștırmalar ve sağlık uzmanlarının görüșleri, süt tüketiminin özellikle yașlııkta önemli olduğunu ve önceki yașlardaki bu tüketim alıșkanlığının insanları birçok hastalık ve rahatsızlıklara karșı koruduğunu ortaya koymaktadır (Ünal ve Besler, 2008). Bu nedenle tüketimin sadece çocuklar için değil, aynı zamanda her yaștan insanlar için artırıması yönünde bilinç çalıșmalarına gerek vardır.

Araștırma sonuçlarına göre Ankara ilinde kırsal alanda yașayan, tarım sektöründe faaliyet gösteren ailelerin süt tüketim düzeyleri oldukça düșüktür. Büyük çoğunluğunun çocuk sahibi olduğu, yoğun fiziksel aktivite gerektiren tarım sektöründe çalıștıkları düșünüldüğünde, makro ve mikro besin öğelerinin büyük bir bölümünü içinde barındıran süt tüketiminin azlığı dikkat çekmekte ve artırılma gerekliliği ortaya çıkmaktadır. Bu süreçte tüketim bilincine yönelik çalıșmalar artırılarak yapılmalıdır. Okulda yer alan çocuklara okul sütü gibi programların tüm yıla yayılarak devam etmesi önemlidir. Bu arada sütün her yaș ve dönem için önemini anlatan basılı ve görsel yayınlara önem verilmelidir. Tüketim bilincin artıșında aileden, okuldan, çevreden ve makro düzeyde hükümet uygulamalarından yararlanmak gerekir. Konuyla ilgili bilinçlendirme çalıșmaları özellikle kırsal alanda yașayan ailelere dengeli beslenme için gerekli olan gıda ürünleri hakkında bilgi verilmesi ve bunun içinde de süt tüketimine gereken önemin verilmesine yönelik sistematik çalıșmalara gerek vardır.

\section{KAYNAKLAR}

Akbay C, Tiryaki G.Y (2007). Tüketicilerin Ambalajlı ve Açık Süt Tüketim Alıșkanlıklarının Karșılaștırmalı Olarak İncelenmesi: Kahramanmaraș Örneği. KSÜ Fen ve Mühendislik Dergisi, 10(1): 89-96.

Anonim (2016a).http://www.milliyet.com.tr/sut-gunlukbesin-ihtiyacinin-pembenar-detay-sagliklibeslenme-2191099/ Erișim Tarihi: 12.12.2016

Anonim (2016b).http://mww.pinarsutum.com/yasagore-sut-tuketimi Erișim Tarihi:12.12.2016

Anonim (2016c). http://m.gidagundemi.com/haber/ turkiyede-sut-ve-sut-urunleri-tuketimi-h9619.html Erișim Tarihi: 15.12.2016

Armağan G, Akbay C(2007). An Econometric Analysis of Urban Households' Animal Products Consumption in Turkey, Applied Economics, 1-8.

Çelik Y, Karlı B, Bilgiç A, Celik S (2005). Șanlıurfa İli Kentsel Alanda Tüketicilerin Süt Tüketim Düzeyleri ve Tüketim Alıșkanlıkları, Tarım Ekonomisi Dergisi 2005; 11(1) : 5 - 12.

Çetinkaya A. (2010). Kafkas Üniversitesi Öğrencilerinin İçme Sütü ve Süt Ürünlerini Tüketim Alıșkanlıklarının Belirlenmesi. Atatürk Üniversitesi Veteriner Bilimleri Dergisi. 5 (2), 73-84.

Düzgüneș O, Kesici T, GürbüzF (1993). İstatistik Metotları (II. Baskı). Ankara Üniversitesi Ziraat Fakültesi Yayınları No:1291, Ders Kitabı: 369, 218 s., Ankara

Erdal G, Tokgöz K (2011). Tüketicilerin Ambalajlı ve Açık Süt Tüketim Tercihlerini Etkileyen Faktörler: Erzincan İli Örneği, KMÜ Sosyal ve Ekonomik Araștırmalar Dergisi 13 (20): $111-115,2011$

Grigg D (1999). Food Consumption in the Mediterranean region. Tijdschrigt Voor Economische en Sociale Geografie, 90(4): 391-409. 
Güngör M, Bulut Y (2008). Ki-Kare Testi Üzerine. Doğu Anadolu Bölgesi Araștırmaları, Elazığ.

Hanta B (1994). Adana ili Kentsel Alanda Hayvansal Gıda Tüketim Yapısı (yüksek lisans tezi, basılmamıș). C..Ü., Fen Bilimleri Enstitüsü, Adana.

Onurlubaș E, Çakırlar H (2016).Tüketicilerin Süt ve Süt Ürünleri Tüketimini Etkileyen Faktörlerin Belirlenmesi Üzerine Bir Araștırma, Çankırı Karatekin Üniversitesi Sosyal Bilimler Enstitüsü Dergisi, 7(1): 217-242.

Sokal R.R, Rohlf F.J (1995). Biometry. The principles and practice of statistics in biological research. Third edition. W.H. Freeman Company. New York.
Șimșek O, Çetin C, Bilgin, B (2005). “istanbul Illinde İçme Sütü Tüketim Alıșkanlıkları ve Bu Alıșkanlıkları Etkileyen Faktörlerin Belirlenmesi Üzerine Bir Araștırma", Tekirdağ Ziraat Fakültesi Dergisi, 2, 1.

Tuik (2016). İstatistiksel Veriler, www.tuik.gov.tr

Ünal N.R, Besler H.T (2008). Beslenmede Sütün Önemi, Sağlık Bakanlığı Yayın No: 727, Ankara.

Yamane T. (2001). Temel Örnekleme Yöntemleri. (Birinci BaskI). Ceviren: Alptekin ESIN, M. Akif BAKIR, Celal AYDIN ve Esen GÜRBÜZSEL. İstanbul. Literatür Yayıncılık. 